\title{
Changes of Mortality and Morbidity of Very Low Birth Weight Infants after Neonatal Intensive Care Unit Strategy Alteration in a Single Center: Comparison with 2015 Korean Neonatal Network Report
}

\author{
Seung Mi Jung, Min Jeong Seok, Ji Yong Chun, and Tae-Jung Sung \\ Department of Pediatrics, Kangnam Sacred Heart Hospital, Hallym University Medical Center, Seoul, Korea
}

\section{ABSTRACT}

Purpose: The purpose of this study was to investigate the outcome after changes in the treatment strategies for very low birth weight infant (VLBWI) in a single neonatal intensive care unit (NICU) center.

Methods: We performed a retrospective review of 300 VLBWI born from 1st January 2010 to 31th December 2016. We compared the outcomes including survival rate, birth weight (BW), gestational age (GA), and morbidities between period I (20102013, P-I) and period II (2014-2016, P-II).

Results: The average survival rate was not different between P-I and P-II. However, the survival rate of $\leq 24$ weeks' GA, 25 weeks' GA, 26 weeks' GA were $57 \%, 69 \%, 93 \%$ respectively in P-II and 31\%, 59\%, 87\% in P-I respectively. The survival rate of infants with birth weight <500 g, 500-749 g, 750-999 g were $100 \%, 55 \%$, 90\% respectively in P- II and $50 \%, 24 \%, 80 \%$, respectively in P-I. The incidence of bronchopulmonary dysplasia (BPD) was higher in P-II than in P-I $(P=0.012)$ and moderate-to-severe BPD was also higher in P-II $(P=0.004)$. Incidence of patent ductus arteriosus (PDA) with treatment, necrotizing enterocolitis (stage $\geq 2$ ), and abnormal brain sonography were significantly lower in P-II $(P=0.027, P=0.032, P=0.005)$. Incidences of retinopathy of prematurity (ROP) with laser treatment and early sepsis were not different.

Conclusion: The survival rate and complications of VLBWI were improved in period II, especially in less than $750 \mathrm{~g}$ and below 26 weeks, except incidence of BPD. Changes of NICU strategies were effective to improve mortality and morbidity in VLBWI.

Key Words: Very low birth weight infant, Mortality, Morbidity, Intensive care unit, Complication

\section{서론}

우리나라는 2015년 출산율이 1.24\%로 Organization for Economic Cooperation and De-
Received: 18 September 2017

Revised: 27 October 2017

Accepted: 31 October 2017

Correspondence to: Tae-Jung Sung

Department of Pediatrics, Kangnam Sacred Heart Hospital, Hallym University Medical Center, 948-1 Daerim-Dong, Yeungdeungpo-gu, Seoul 07441, Korea

Tel: +82-2-829-5142

Fax: +82-2-829-4469

E-mail: neosung@hallym.or.kr

Copyright(c)

By Korean Society of Neonatology.

All right reserved.

This is an Open-Access article distributed under the terms of the Creative Commons Attribution Non-Commercial License (http://creativecommons.org/licenses/ by-nc/4.0), which permits unrestricted non-commercial use, distribution, and reproduction in any medium, provided the original work is properly cited. 
velopment (OECD) 국가 중 가장 낮은 초저출산 국가중의 하나로 보 고되고 있다 ${ }^{1)}$. 그러나, 결혼, 출산 연령이 올라가고 불임 시술이 늘 어나면서 37 주 미만의 미숙아와 같은 고위험신생아수는 해마다 급 격하게 증가하고 있다 ${ }^{1,2)}$. 2010년 발표한 World Health Organization (WHO) 보고서에 의하면 저체중출생아의 비율이 한국은 $5 \%$, 일본 은 9.6\%, 미국은 8.2\%로 보고되었고, 2015년 우리나라 통계청 인구 동향조사 데이터에 따르면 2,500 g 미만의 저체중출생아(low birth weight infants, LBWI) 의 출생률은 $5.7 \%, 1,500 \mathrm{~g}$ 미만의 극소저체 중출생아(very low birth weight infants, VLBWI)의 출생률은 $0.7 \%$ 로 보고되었으며 매년 증가하는 것으로 알려져 있다 ${ }^{3)}$. 이중 특히 VLBWI의 출생률 증가는 의료기술의 발전 및 초미숙아에 대한 적극 적인 처치의 증가로 인한 것이라고 할 수 있다 ${ }^{4,5}$.

세계적으로 VLBWI의 생존율은 1990년대 전반에는 $82 \%$, 후반에 는 $85.8 \%$ 로 높아진 생존율을 보인다 ${ }^{6,7)}$. 미국의 통계를 보면 1990 년대 초반에는 $80 \%$ 정도였던 생존율이 중반에는 $84 \%$, 후반에는 $85 \%$ 였으며 ${ }^{8)}$, 신생아학이 발달한 일본의 경우 2003 년에 $89 \%$ 의 VLBWI 생존율을 보고한 바 있달. 우리나라의 경우 1990년대 초 반에 $65.8 \%$ 였던 생존율이 후반에는 $71.3 \%$ 로 현저하게 향상되었으 며 2000년대 초반 $78.8 \%$, 후반에는 $85.7 \%$ 로 비약적인 생존율 증가 를 보이고 있고, 생존 가능한 출생 체중과 연령도 점차 낮아지고 있 다 ${ }^{10}$. 국제적으로는 이러한 VLBWI 의 생존율을 합병증 없이 높이는 것이 각 신생아 중환자실(neonatal intensive care unit, NICU) 치료 수준의 지표로 볼 수 있으며, VLBWI 의 사망률 및 유병률이 그 국가 의 보건의료수준의 척도로 여겨지기도 한다 ${ }^{1)}$.

본 저자들은 이전 연구에서 1997년부터 2008년까지 본원 NICU에 서의 생존율과 이환율에 어떤 변화가 있는지 알아보는 연구를 하여 결론적으로 평균 재태주수가 감소하였으나 생존율은 증가되었고 이 에 따라 합병증이 증가하였다는 결과를 발표하였다 ${ }^{11}$. 이후 2013년 에 보고된 초미숙아 생존 한계를 극복하기 위해 최신 치료경향을 참 고로 NICU 치료 전략을 변경하여 초미숙아의 생존율을 높이고 장 기적인 합병증의 발생을 낮추려는 노력을 하였고, 그러한 노력이 단 일기관에서 초미숙아를 포함한 VLBWI 의 생존율과 이환율에 어떤 영향을 끼쳤는지 알아보고자 본 연구를 진행하였다 ${ }^{12)}$. 또한 대한신 생아학회에서 전국 $\mathrm{NICU}$ 를 대상으로 VBLWI의 등록 및 자료분석, 질 관리, 교육, 질병 이환율 및 사망률 보고를 위해 2013년에 질병관 리본부 및 국립보건원과 함께 발족한 한국 신생아네트워크(Korean Neonatal Network, KNN) 의 2015년 연차보고서 자료와 함께 비교 하여 본원의 향후 개선점이 무엇인지 알아보았다 ${ }^{13)}$.

\section{대상 및 방법}

\section{1. 대상 및 방법}

2010년 1월부터 2016년 12월까지 본원 NICU에 입원한 37주 이하 의 미숙아 1,216 명 중에서 $1,500 \mathrm{~g}$ 미만의 VLBWI는 341 명이었으며, 이 중에서 출생 후 48 시간 이내 사망한 18 명, 타 병원에서 전원 온 5 명, 타 병원으로 전원 된 16 명, 선천성 기형 2 명을 제외한 300 명을 대 상으로 하였다. 본원의 치료 전략 변화가 본격적으로 시작된 2014년 을 기준으로 2010년부터 2013년까지를 전기(Period I, 171례), 2014 년부터 2016년까지를 후기(Period II, 129례)로 하여, VBLWI 의 생존 율 및 이환 질환 등을 병록지 검토를 통해 후향적으로 조사하였다.

2013년 발표된 Chang과 Park ${ }^{12)}$ 및 다른 문헌들을 참고로 하여 본 원 NICU에서 실행 가능한 다음과 같은 원칙들을 2014년 부터 적용 하기 시작하였다. 본원의 경우 2014년 부터 고가습이 가능한 이중 벽 인큐베이터(Giraffe Omnibed, GE Healthcare, Maryland, USA와 Dual Incui, Atom Medical, Tokyo, Japan)를 사용하여 출생 초기에 최소 4 일 동안 초미숙아들에게 인큐베이터 내 습도를 $80 \%$ 이상으 로 유지하는 고가습 치료를 시작하였고, 이에 따른 불감수분소실을 줄일 수 있게 되어 출생 직후에는 하루 총 수액량을 $60 \mathrm{~mL} / \mathrm{kg}$ 로 시 작하고 그 이후로는 체중, 소변량, 혈액 내 전해질 수치를 관찰하며 총 수액량을 조절하는 수액제한요법을 실시하였다. 동맥관 개존증 (patent ductus arteriosus, PDA)이 있는 경우 예방적 치료 보다는 다 음과 같은 경우에만 치료를 고려하였는데, 심초음파상 동맥관 지름 이 $1.5 \mathrm{~mm}$ 이상일 경우, 기계환기 요구도가 증가하는 경우, 울혈성 심부전이나 심비대를 보일 경우, 저혈압이 발생하는 경우, 다른 이 유로 설명되지 않는 대사성 산증 $(\mathrm{pH}<7.25)$ 을 보이는 경우 등이다 ${ }^{14)}$. 모든 30 주 미만 미숙아는 출생 직후 기도 삽관을 하고 예방적으 로 폐표면 활성제를 투여하였으며, 투여 이후 가능한 한 빠른 시간 안에 발관하고 비강지속양압치료를 적극적으로 시도하여 침습적 인 공호흡기 치료를 최소화하려고 노력하였다. 또 측정한 혈압이 같은 재태주수에 비해 10 백분위수 이하인 경우를 저혈압으로 판단하였 는데, 이때도 전신 관류 상태가 양호하다면 불필요한 혈압 상승제사 용을 자제하는 허용성 저혈압치료를 하였다 ${ }^{15)}$. 호흡곤란을 보이지 않고 전신 감염의 증거가 없는 미숙아에서는 가능한 한 빨리 조기 장 관영양공급을 시행하였으며, 불가능할 경우에는 미숙아의 구강 점 막에 산모의 초유를 묻혀주는 초유구강케어를 시작하였다 ${ }^{16)}$. 그리 고 저온살균 모유 관리로 모유수유를 독려하였으며, 신생아 전담의 증가 및 전담간호사 배치 등 전문인력을 보강하여 보다 강화된 밀착 치료를 하는 등 많은 치료 전략의 변화가 있었으므로 이를 기준으로 전기와 후기로 나누어 조사하였다.

조사 항목 중 신생아 관련 요인은 생존율과 함께 기관지 폐형성 이상(bronchopulmonary dysplasia, BPD), 치료가 필요했던 PDA, 치료가 필요했던 미숙아 망막증(retinopathy of prematurity, ROP), 
뇌실 내 출혈(intravascular hemorrhage, IVH), 뇌백질연화증(periventricular leukomalacia, PVL), 괴사성 장염(necrotizing enterocolitis, NEC), 조기 패혈증 및 후기 패혈증의 이환율을 확인하였다. 생존아는 NICU 입원기간동안 생존한 경우로 하였고, 생존율은 (생 존아/VLBWI $\times 100$ 으로 산출하였다. 신생아 호흡곤란증은 본원의 경우 위에서 언급했듯이 폐표면활성제의 예방적 투여 요법을 실시 하고 있어 정확한 유병률을 파악하기 어려우므로 이번 연구에서는 제외하였다. $\mathrm{BPD}$ 는 $21 \%$ 가 넘는 산소를 적어도 28 일 이상 투여하 는 산소의존도가 지속되는 경우로 정의하였고, 퇴원 전 혹은 재태주 수 36주 시점에서 산소요구량에 따라 경증, 중등증, 중증으로 나누 어 그 중에서도 증등증과 중증을 심한 $\mathrm{BPD}$ 로 분류하여 조사하였다 ${ }^{17)} \mathrm{PDA}$ 진단은 심잡음이 들리는 경우, 심초음파 검사를 시행하여 확진 된 경우로 하였으며 ${ }^{18)}$, 혈역학적으로 불안정한 경우 ibuprofen 약물치료를 시작하였고 이후 수술을 고려하였다. 뇌초음파 이상의 정의는 Papile 등 $^{19)}$ 의 분류에 따라 뇌 초음파 검사에서 확인된 grade 2 이상의 IVH가 지속적으로 관찰된 경우거나, PVL이 진단된 경우로 하였다. 본원의 미숙아들은 전담 안과 의사에 의해 1-2주 간격으로 $\mathrm{ROP}$ 검사를 하였는데, 치료가 필요한 $\mathrm{ROP}$ 는 안과 의사에 의해 진행 성으로 판단하여 레이저 치료를 시행한 경우로 정의하였다. NEC는 Bell 등 ${ }^{20)}$ 의 분류상 stage II 이상인 경우로 정의하였다. 여기에서 얻 은 결과는 $\mathrm{KNN}$ 의 2015년 연차보고서 자료와 함께 비교하였다.

통계 분석은 SPSS ver. 21.0 (IBM Corp., Armonk, NY, USA)을 이 용하였고 연속변수인 결과는 $t$-test로, 범주형 변수인 경우는 Chisquare test 혹은 Mann-Whitney test를 이용하여 VLBWI의 발생 빈 도, 생존율, 이환율, 이환 질환 등을 기간에 따라 비교하였다. 모든 분석에서 $P$ 값이 0.05 미만인 경우를 통계적으로 유의한 것으로 간주 하였다.

\section{결과}

\section{VLBWI의 재태주수 및 출생 체중별 분포와 생존율}

우선 재태주수를 24주 이하와 25주, 26주, 27주, 28주 이상으로 세 분하여 미숙아의 분포를 살펴보면, 전기와 후기를 비교했을 때 I기 에서는 $\leq 24$ 주가 26명(15.2\%), 25주 17명(9.9\%), 26주 15명(8.8\%), 27 주 21명(12.3\%), $\geq 28$ 주 92명(53.8\%)이었고, II기에서는 $\leq 24$ 주 23명(17.9\%), 25주 16명(12.4\%), 26주 14명(10.9\%), 27주 15명(11.6 $\%), \geq 28$ 주 61명(47.3\%)으로 I기보다 II기에서 26주 이하 미숙아가 좀더 많은 분포를 보였다. 출생체중을 $250 \mathrm{~g}$ 단위로 나누어 미숙아 의 분포를 살펴보면 500-749 g의 미숙아가 I기에서는 25명(14.6\%), II기에서는 29명(22.5\%)로 증가하였으며 $750 \mathrm{~g}$ 이상의 미숙아 분포 는 큰 차이를 보이지 않았다. 따라서 II기에 주수가 더 어리고 체중이 더 작은 미숙아가 많아진 것을 알 수 있었다(Table 1).

전체 대상아의 생존율은 I기에는 82.5\%(141/171), II기에는 86\% $(111 / 129)$ 로 통계학적으로 의미 있는 차이는 없었으나 $(P=0.401)$, 28 주 미만에서 재태주수를 세분화하여 살펴보면 24주 이하는 I기 $31 \%$ (8/26), II기 57\% (13/23), 25주에서는 I기 59\% (10/17), II기 69\% $(11 / 16)$ 로 대상아가 적어서 통계학적으로는 의미 있게 나오지는 않 았으나 $(P=0.088, P=0.354)$ 생존율이 높아지는 경향을 보였으며, 26 주 이상에서는 차이를 확인할 수 없었다(Figure 1). 재태주수를 24 주 이하와 25-28주, 29-32주, 33주 이상의 네 군으로 나누어 2015년 $\mathrm{KNN}$ 자료와 비교해 보았을 때, 특히 24 주 이하 미숙아의 생존율이 증가하여 $\mathrm{I}$ 기에는 $31 \%$ 로 $\mathrm{KNN}$ 에서 보고한 $42.7 \%$ 보다 낮았으나, II 기는 $57 \%$ 로 그보다 더 높은 생존율을 보인다(Table 1).

출생 체중별로 나누었을 때는 $500 \mathrm{~g}$ 미만에서 두 군 모두 한 명씩 의 생존아가 있었고, 500-749 g에서는 I기에서는 21\% (5/25), II기에

Table 1. Gestational Age and Birth Weight-specific Distribution and Survival Rate of Very Low Birth Weight Infant

\begin{tabular}{|c|c|c|c|c|c|c|}
\hline & \multicolumn{2}{|c|}{ Period I (n=171) } & \multicolumn{2}{|c|}{ Period II (n=129) } & \multirow{2}{*}{$P$-value } & \multirow{2}{*}{ KNN survival report (\%) } \\
\hline & Total birth, n (\%) & Survival, n (\%) & Total birth (\%) & Survival (\%) & & \\
\hline \multicolumn{7}{|c|}{ Gestational age (wks) } \\
\hline $25^{+0}-28^{+6}$ & $82(48.0)$ & $71(86.6)$ & $61(47.3)$ & $53(86.9)$ & 0.958 & 85.0 \\
\hline $29^{+0}-32^{+6}$ & $53(31.0)$ & $52(98.1)$ & $42(32.6)$ & $42(100)$ & 1.000 & 96.6 \\
\hline$<500$ & $2(1.2)$ & $1(50)$ & $1(0.8)$ & $1(100)$ & 1.000 & 27.3 \\
\hline $500-749$ & $25(14.6)$ & $6(24.0)$ & $29(22.5)$ & $16(55.2)$ & 0.028 & 57.7 \\
\hline $750-999$ & $40(23.4)$ & $32(80)$ & $30(23.3)$ & $27(90)$ & 0.331 & 83.3 \\
\hline $1,000-1,249$ & $49(28.7)$ & $48(98)$ & $38(29.5)$ & $36(95)$ & 0.578 & 93.0 \\
\hline
\end{tabular}

Survival rate $(\%)=($ number of survival/total number at specific gestational age or birth weight $) \times 100$. Abbreviation: KNN, Korean Neonatal Network. 


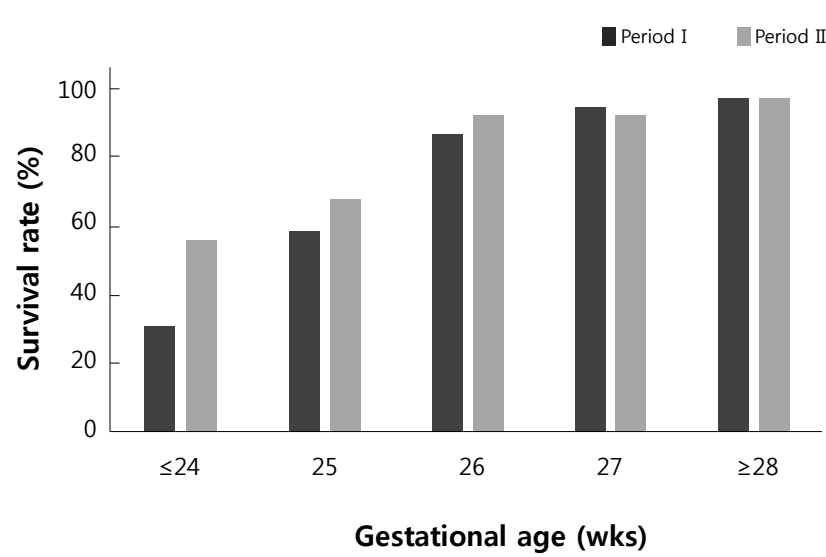

Figure 1. Survival rate of very low birth weight infant per gestational age. Figure 1 demonstrates improved survival rate of very low birth weight infant in period II. The survival rate of $\leq 24$ weeks' gestational age was $31 \%$ in P-I and $57 \%$ in P-II. Survival rate of 25 weeks' gestational age was $59 \%$ in P-I and $69 \%$ in P-II.

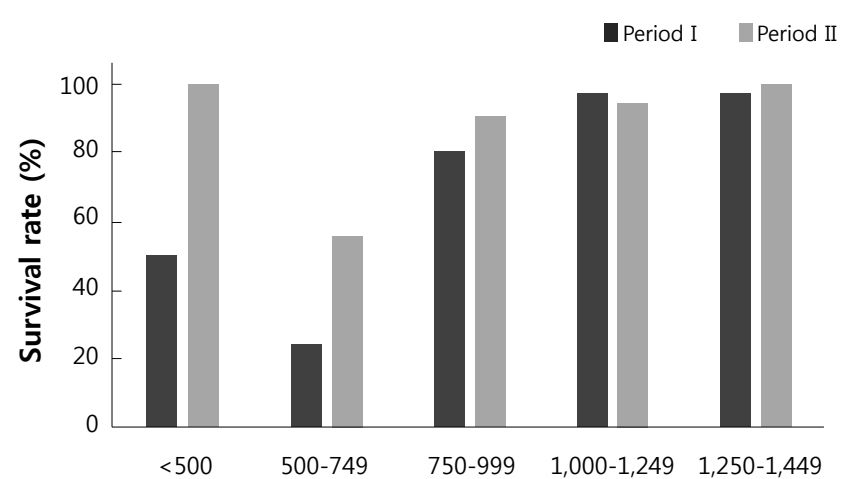

Birth weight (g)

Figure 2. Survival rate of very low birth weight infant per birth weight. The survival rate of very low birth weight infant born 500-999 $\mathrm{g}$ was increased in period II. Each survival rate of Infants with birth weight $500-749 \mathrm{~g}$, $750-999 \mathrm{~g}$ were $24 \%, 80 \%$ respectively in P-I and 55\%, 90\% respectively in P-II. ${ }^{*} P<0.005$.

서는 57\% (16/29)의 생존율을 보였으며, 750-999 g은 I기 80\%, II기 $90 \%, 1,000-1,249 \mathrm{~g}$ 은 각각 $98 \%, 95 \%$ 의 생존율을 보였다. 이 중 500$749 \mathrm{~g}$ 의 미숙아 군에서 특히 생존율의 향상이 있음을 알 수 있는데 (Figure 2), I기에는 KNN의 전국 평균 $57.7 \%$ 에 미치지 못하는 생존 율을 보였던 것에 비해 II기의 생존율은 $55.2 \%$ 로 상승하여 그와 비 슷한 수준을 보이고 있다. $750 \mathrm{~g}$ 이상의 미숙아에서는 I기와 II기에 서 모두 KNN의 자료와 비슷한 생존율을 볼 수 있었다(Table 1).

\section{VLBWI의 임상적 특성}

평균 재태주수는 I기에는 $27.5 \pm 3.0$ 주, II기에서는 $27.3 \pm 2.6$ 주였으
며, 평균 출생체중은 I기에서는 $1,065.4 \pm 277.2 \mathrm{~g}$, II기에서는 $1,017.9$ $\pm 283.3 \mathrm{~g}$ 으로 I기와 II기의 평균 재태주수 및 출생체중에는 유의한 차이가 없었다. 2015년 KNN 연차보고서에서의 전국 평균 재태주 수는 28.9주로, 평균보다 재태주수가 어린 미숙아들이 많았다고 볼 수 있다. 산모의 나이는 II기에서 평균 33.5 \pm 3 .9세로, I기 평균 32.6 \pm 3.7 보다 통계학적으로 의미 있게 높았으므로 점점 더 늦은 출산 을 하는 경향이 있다는 것을 알 수 있었으며 KNN 자료와 비교하였 을 때는 평균 33세로 비슷하였다. 인공수정 및 다태아 임신은 I기와 II기에 차이가 없었으나 전국 평균보다는 그 빈도가 적었다. 1 분, 5 분 아프가 점수는 I기 및 II기에 각각 $3.2 \pm 1.9$ vs. $3.1 \pm 1.9$ 점, $5.1 \pm 2.1$ vs. $3.8 \pm 2$.6점으로 1 분 아프가 점수는 통계학적 차이가 없었지만 II 기의 5 분 아프가 점수가 $\mathrm{I}$ 기에 비해 유의하게 낮았으며 $(P=0.738, P=$ $0.00), \mathrm{KNN}$ 의 전국 평균 6.8 점보다도 낮은 점수를 보였다. 평균 재 원 기간은 I기에 $58.8 \pm 32.6$ 일, II기에서는 70.0 39.0 일로 나타나 II 기의 미숙아들이 더 오랜 기간 동안 NICU에 입 원하였다 $(P=0.007)$. 총 인공호흡기 사용기간의 경우 I기에서 $13.5 \pm 20.7$ 일, II기에서는 $22.1 \pm 24.8$ 일이었고 $(P=0.001)$, 이 중 침습적 인공호흡기 사용기간은

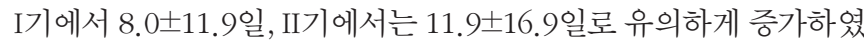
다 $(P=0.020)$. 비침습적 인공호흡기 사용기간은 $\mathrm{I}$ 기에서 $3.6 \pm 8.2$ 일, II기에서는 $11.4 \pm 16.0$ 일이었고 $(P=0.000)$, 총 산소 투여 기간은 I기 에는 $29.3 \pm 32.9$ 일, II기에서는 $42.6 \pm 39.4$ 일로 II기에서 인공호흡기 및 산소투여기간이 모두 통계학적으로 의미 있게 길었다(Table 2).

\section{3. 미숙아의 주요 합병증 발생 빈도}

미숙아의 주요 합병증을 살펴보았을 때, $\mathrm{BPD}$ 는 I기에서 $45.8 \%$, II기에서 $61.6 \%$ 로 더 많이 발생하였고 $(P=0.012)$, 특히 중등도 이상 의 $\mathrm{BPD}$ 가 II기에서 통계학적으로 의미 있게 증가하였다 $(P=0.004)$. $2015 \mathrm{KNN}$ 보고서와 비교했을 때 BPD 발생률이 I기에서는 KNN의 평균과 비슷하였으나 2기에서는 그보다 높은 것을 확인할 수 있다. 중증 $\mathrm{BPD}$ 의 경우 재태주수가 어리거나 출생 체중이 작은 미숙아들 에서 많이 발생한다는 것이 알려져 있는데, 이러한 미숙아들은 사망 률이 높기 때문에 BPD가 진단되기 전에 사망할 가능성을 생각해 볼 수 있다. 따라서 중증의 BPD와 사망을 묶어 비교해 보았으며, 여기 서는 I기 $20.5 \%$, II기 $21.7 \%$ 로 유의미한 차이를 보이지 않았다. 약물 치료 혹은 수술적 치료를 받은 PDA는 I기에서는 $23 \%$ 였으나 II기에 서는 $13 \%$ 로 감소하였고 $(P=0.027), 2015$ 년 $\mathrm{KNN}$ 자료에서의 평균은 $38.8 \%$ 로 확인되었다. 레이저를 시행한 ROP는 I기 $22 \%$, II기 $18 \%$ 로 두군 간에는 차이가 없었으나 두 기간 모두 2015년 평균인 6.8\%보다 발생률이 높았다. Stage II 이상인 NEC의 경우 I기에서는 $6 \%$ 였으나, II기에서는 $1 \%$ 로 감소하였으며 $(P=0.032) \mathrm{KNN}$ 의 2015년 NEC 발생 률인 $6.1 \%$ 보다 적었다. 조기 패혈증은 I기에서 $14 \%$, II기에서 $10 \%$ 로 줄어드는 경향을 보였으나 통계학적으로 의미는 없었으며, 후기 패혈증은 I기에서 $21.3 \%$, I기에서 $20.7 \%$ 로 비슷한 빈도를 보였다. 
Table 2. Clinical Characteristics of Very Low Birth Weight Infant

\begin{tabular}{|c|c|c|c|c|}
\hline & Period I $(n=171)$ & Period II $(n=129)$ & $P$-value & KNN report (\%) \\
\hline Gestational age (wks) & $27.5 \pm 3.0$ & $27.3 \pm 2.6$ & 0.139 & 28.9 \\
\hline Birth weight (g) & $1,065.4 \pm 277.2$ & $1017.9 \pm 283.3$ & 0.147 & $1,075.3 \pm 286.0$ \\
\hline Maternal age (y) & $32.6 \pm 3.7$ & $33.5 \pm 3.9$ & 0.036 & 33.0 \\
\hline ART & $27(15.9)$ & $24(18.6)$ & 0.535 & 23.7 \\
\hline Multiple gestation & $36(21.1)$ & $27(20.9)$ & 0.979 & 35.9 \\
\hline Sex (male) & $84(49.1)$ & $64(49.6)$ & 0.933 & 51.1 \\
\hline Apgar score at $1 \mathrm{~min}$ & $3.2 \pm 1.9$ & $3.1 \pm 1.9$ & 0.738 & 4.5 \\
\hline Apgar score at $5 \mathrm{~min}$ & $5.1 \pm 2.1$ & $3.8 \pm 2.6$ & 0.000 & 6.8 \\
\hline Duration of hospitalization (d) & $58.8 \pm 32.6$ & $70.0 \pm 39.0$ & 0.007 & $64 \pm 42$ \\
\hline Duration of total ventilation apply (d) & $13.5 \pm 20.7$ & $22.1 \pm 24.8$ & 0.001 & $\mathrm{~N} / \mathrm{A}$ \\
\hline Duration of invasive ventilation (d) & $8.0 \pm 11.9$ & $11.9 \pm 16.9$ & 0.020 & $13.7 \pm 27.3$ \\
\hline Duration of non-invasive ventilation (d) & $3.6 \pm 8.2$ & $11.4 \pm 16.0$ & 0.000 & $17.2 \pm 21.3$ \\
\hline Duration of total oxygen apply (d) & $29.3 \pm 32.9$ & $42.6 \pm 39.4$ & 0.002 & $\mathrm{~N} / \mathrm{A}$ \\
\hline
\end{tabular}

Data presented as mean \pm SD or $\mathrm{n}(\%)$.

Abbreviations: KNN, Korean Neonatal Network; ART, assisted reproductive technology.

뇌 초음파 이상의 경우 I기에서는 $18 \%, \mathrm{II}$ 기에서는 $6 \%$ 로 II기에서 발 생빈도가 줄어든 것을 알 수 있었다 $(P=0.005$, Table 3$)$.

\section{고찰}

우리나라의 신생아학은 지속적으로 발전하고 있으며 다양한 분 야에서 여러가지 의료기술의 발달로 인해 최근에는 더욱 더 작고 어 린 미숙아들이 태어나는 추세이다. 본 연구에서 연자들은 단일기관 에서 초미숙아의 최신 치료경향을 적극적으로 적용한 2014년 이후 의 VLBWI의 생존율 및 합병증의 변화를 알아보고자 하였다. 또한 $\mathrm{KNN}$ 의 2015년 연차보고서를 활용하여 본원 NICU 미숙아 치료 성 적의 현재 위치를 확인하며, 앞으로의 치료 목표를 재설정하고자 하 였다.

2013년 Smith 등 $^{21)}$ 의 보고에 의하면 생존한계 근처의 초미숙아 를 적극적으로 치료할수록 생존한계 위의 좀 더 성숙한 미숙아들의 생존율이 향상되고 장기적인 예후가 향상되었다고 한다. 저자들은 2014년 이후 치료 전략의 변화와 함께 23주 이하의 미숙아에서도 더 욱 적극적인 치료를 하려고 노력하였는데, 위 결과에서도 볼 수 있듯 이 24 주 이하의 미숙아의 생존율이 높아지는 추세를 보였으며, 출생 체중으로 보았을 때는 특히 500-749 g의 더 작은 미숙아에서 생존율 의 확연한 증가를 보여 생존한계 근처의 초미숙아들을 좀 더 적극적 으로 치료할 필요가 있다는 것을 알 수 있었다. 생존한계의 정의는 각 시대에 따라 또는 나라별로 혹은 각 병원의 센터가 처한 상황과 여건 등에 따라 다를 수는 있지만 ${ }^{7,12,22)}$. 본원의 경우 현재 $500 \mathrm{~g}$ 이상 혹은 23 주 이상의 미숙아인 경우에는 적극적으로 소생술을 실시하
고 있으며, 그 이하인 경우에는 의료진과 보호자가 충분히 상의하여 치료 여부를 결정하고 있다.

$\mathrm{KNN}$ 의 연차보고서와 비교해 보았을 때 본원 미숙아들의 특징으 로는 더 어린 재태주수에서 출생하고, 인공수정이나 다태아의 비율 은 적으며, 5 분 아프가 점수가 더 낮고, 오랜 기간 동안 입원하며 침 습적 혹은 비침습적 인공호흡기 사용기간과 산소의 투여 기간이 길 다는 점이 있다. 이와 같은 특징들은 단순히 생존율 뿐만 아니라 장 기적인 합병증과도 많은 관련이 있을 것으로 생각된다. 특히 합병증 중에서도 $\mathrm{BPD}$ 와 $\mathrm{ROP}$ 는 재태주수와 출생체중뿐만 아니라 고농도 산소요법 등으로 악화된다고 알려져 있다 ${ }^{16,23)}$. $\mathrm{BPD}$ 의 경우 I기보다 II기에서 더 높은 발생률을 보였고 중등도 이상의 BPD 역시 II기에서 증가하였는데, 이는 II기에서 더 작고 더 어린 미숙아가 많았으며 산 소 치료 기간 또한 증가했기 때문이라고 추측된다. 또한 최근 들어 비침습적 인공호흡기를 적극적으로 사용하면서, 최근에는 미숙아 무호흡 발생시 이전에 사용하였던 약물치료 외에도 고유량 비강 캐 뉼라(high flow nasal cannula)를 사용하는 빈도가 증가하여 총 산소 사용기간이 늘어났던 것도 고려해야 할 대상이며 호흡기 세포융합 바이러스(Respiratory syncytial virus) 면역글로불린의 보험 수가 인 정기준 확대에 따라 $\mathrm{BPD}$ 의 진단이 증가한 점도 생각해 볼 수 있다. 중증 $\mathrm{BPD}$ 와 사망을 묶어서 비교했을 때는 I기와 II에서 차이를 보이 지 않았으며, 이를 고려해 보았을 때 I기에서는 36주 이전에 사망했 던 미숙아들이 II기에서는 생존하여 중증 BPD가 더 많이 발생했다 고 생각된다. 그러나 $\mathrm{KNN}$ 자료와 비교해 보았을 때에도 전체적인 $\mathrm{BPD}$ 발생률이 평균보다 높았으며, 치료가 필요한 $\mathrm{ROP}$ 역시 평균 발 생률보다 확연히 높았다는 점에서 추후 본원 산소 치료 전략의 재검 토가 필요할 것이다. 
Table 3. Comparison of Neonatal Morbidities of Very Low Birth Weight Infant between Two Periods

\begin{tabular}{|c|c|c|c|c|}
\hline & Period I $(n=171)$ & Period II $(n=129)$ & $P$-value & KNN report (\%) \\
\hline BPD, n (\%) & $66 / 144^{*}(45.8)$ & $69 / 112^{*}(61.6)$ & 0.012 & 47.0 \\
\hline$\leq 24^{+6}$ & $9(100)$ & $14(100)$ & 1.000 & \\
\hline $25^{+0}-28^{+6}$ & $49(67.1)$ & $43(81.1)$ & 0.104 & \\
\hline Moderate-to-severe BPD, n (\%) & $30 / 142^{\dagger}(21.1)$ & $42 / 112^{\dagger}(37.5)$ & 0.004 & 28.0 \\
\hline$\leq 24^{+6}$ & $9(100)$ & $12(85.7)$ & 0.502 & \\
\hline $25^{+0}-28^{+6}$ & $18(25.4)$ & $27(50.9)$ & 0.003 & \\
\hline Severe BPD or death, n (\%) & $35 / 171(20.5)$ & $28 / 129(21.7)$ & 0.794 & N/A \\
\hline$\leq 24^{+6}$ & $20(76.9)$ & $14(60.9)$ & 0.352 & \\
\hline $25+0-28+6$ & $14(17.1)$ & $14(23.0)$ & 0.401 & \\
\hline PDA with medication \pm operation, $\mathrm{n}(\%)$ & $36 / 156^{\ddagger}(23.1)$ & $15 / 119^{\neq}(12.6)$ & 0.027 & 38.8 \\
\hline$\leq 24^{+6}$ & $7(41.2)$ & $5(29.4)$ & 0.721 & \\
\hline $25^{+0}-28^{+6}$ & $22(28.6)$ & $7(12.3)$ & 0.024 & \\
\hline ROP with laser treatment, $\mathrm{n}(\%)$ & $32 / 149 \S(21.5)$ & $21 / 115^{\S}(18.3)$ & 0.518 & 6.8 \\
\hline$\leq 24^{+6}$ & $5(35.7)$ & $7(43.8)$ & 0.722 & \\
\hline $25^{+0}-28^{+6}$ & $27(37.0)$ & $13(24.1)$ & 0.129 & \\
\hline Early-onset sepsis, n (\%) & $23 / 171(13.5)$ & $12 / 122(9.8)$ & 0.268 & N/A \\
\hline$\leq 24^{+6}$ & $8(40)$ & $5(26.3)$ & 0.501 & \\
\hline $25^{+0}-28^{+6}$ & $11(13.8)$ & $5(8.6)$ & 0.427 & \\
\hline Late-onset sepsis, n (\%) & $33 / 155^{\| \prime}(21.3)$ & $25 / 122^{\|}(20.7)$ & 1.000 & $\mathrm{~N} / \mathrm{A}$ \\
\hline$\leq 24^{+6}$ & $5(33.3)$ & $7(36.8)$ & 0.832 & \\
\hline $25^{+0}-28^{+6}$ & $19(19.0)$ & $10(13.0)$ & 0.313 & \\
\hline NEC (stage $\geq \mathrm{II}), \mathrm{n}(\%)$ & $11 / 171(6.4)$ & $1 / 120(0.8)$ & 0.032 & 6.1 \\
\hline$\leq 24^{+6}$ & $5(31.3)$ & $0(0)$ & 0.013 & \\
\hline $25^{+0}-28^{+6}$ & $6(7.8)$ & $1(1.8)$ & 0.238 & \\
\hline Abnormal Brain sonography, n (\%) & $26 / 149^{\top}(17.6)$ & $7 / 116^{\varphi}(6.0)$ & 0.005 & $\mathrm{~N} / \mathrm{A}$ \\
\hline$\leq 24^{+6}$ & $5(45.5)$ & $2(12.5)$ & 0.084 & \\
\hline $25^{+0}-28^{+6}$ & $17(22.7)$ & $4(7.3)$ & 0.018 & \\
\hline
\end{tabular}

* Infants who died before 28 days after birth were excluded.

${ }^{\dagger}$ Infants who died before 36 th postmenstrual weeks were excluded.

*Infants who died before conducting echocardiogram were excluded.

${ }^{\S}$ Infants who did not perform fundus examination were excluded.

"Infants who died before 7 days after birth were excluded.

"Infants who died before conducting brain sonogram were excluded.

Abbreviations: BPD, bronchopulmonary dysplasia; PDA, patent ductus arteriosus; ROP, retinopathy of prematurity; NEC, necrotizing enterocolitis.

치료를 필요로 하는 PDA의 경우 I기에 비해 II기에 $12.6 \%$ 로 의미 있게 감소하였고, 이는 2015 년 $\mathrm{KNN}$ 자료의 $39 \%$ 보다 현저히 낮은 것이다. 이것은 증상이 있는 PDA에만 치료를 고려한 것이 한 원인 일 것이고, 또한 치료 전략 변화 중 하나인 고가습 인큐베이터를 이 용한 수액제한요법이 유효한 것으로 생각된다. $\mathrm{BPD}$ 의 보존적 치료 중 하나인 수액제한요법은 아직 그 정확한 효과에 대해서는 논란이 있으나, 좌심실의 전부하를 감소시켜 전신 혈류가 감소하면서 $\mathrm{PDA}$ 의 발생률을 감소시킨다고 알려져 있다 ${ }^{24)}$.

한편, 생존한계의 초미숙아들은 보통 생후 일주일 혹은 한달 내 사망할 확률이 매우 높고, VLBWI의 사망원인으로는 병원 내 감염
이 가장 많다고 보고되고 있어 미숙아의 생존율을 높이기 위해서는 감염의 치료 전략이 무엇보다 중요하다 ${ }^{20,25,26)}$. 본 연구에서는 I기에 $14 \%$ 였던 조기패혈증이 II기에는 $10 \%$ 로 줄어드는 경향을 보였으나 통계학적으로 유의하지는 않았고, 후기 패혈증의 발생률은 두 기간 에서 차이가 없었다. 패혈증의 발생을 막기 위해서 2014년에 새로운 치료방법들과 함께 이미 잘 알려진 최소한의 예방적 항생제 사용, 피 부손상방지, 조기 모유수유 권장, 손 씻기 등을 다시 교육하고 정립 하였으나 아직 효과가 보이고 있지 않는 것으로 밝혀져, 위와 같은 사항들을 앞으로도 더욱 유의하여 치료할 필요가 있다. 그 밖에 괴 사성 장염은 조기 장관영양공급, 개별 총 정맥영양공급, 초유 구강 
케어 및 허용성 고혈당 전략 등을 적용한 결과 I기에 $\mathrm{KNN}$ 평균 $6.1 \%$ 와 비슷했던 발생율이 II기에서 $1 \%$ 로 현저히 감소하였다 ${ }^{27-29)} .2$ 기 이 상의 IVH나 PVL의 발생율도 I기에 비해 II기에 감소하였는데, 이전 에 혈압 상승제를 빈번하게 사용하였던 것에 비해 허용성 저혈압 치 료를 한 것이 한 원인이 될 수 있겠다 ${ }^{14)}$.

결론적으로 본원 NICU에 입원해 치료를 받았던 VLBWI의 생존율 과 이환율을 치료전략의 변화를 기준으로 전기와 후기로 나누어 살 펴보았을 때 후반기에 더 작고 더 어린 미숙아가 많이 태어나는 경향 을 보였고, 그 중 25 주 이하와 $750 \mathrm{~g}$ 이하의 생존율이 높아진 것을 알 수 있었다. 미숙아 관련 합병증 및 장기적인 예후측면에서는 PDA, $\mathrm{NEC}, \mathrm{IVH}$ 및 PVL 등의 발생률이 후기에 감소하여 치료 전략의 변화 가 효과적이었다고 생각되나 $\mathrm{BPD}$ 와 $\mathrm{ROP}$ 의 발생률은 증가하였으 며, $\mathrm{KNN}$ 자료와 비교해 보았을 때도 총 산소 투여 기간이나 침습적 인공호흡기 사용기간이 길어 앞으로 좀 더 엄격한 산소치료전략을 다시 한번 확립하고 더불어 퇴원 후의 신경 발달 평가에 대한 연구를 지속하여 장기적인 예후에 대한 연구가 필요하다고 생각된다.

\section{REFERENCES}

1) The Executive Committee of Korean Neonatal Networt. 2015 Korean Neonatal Network Annual Report: Korean Centers for Disease Control and Prevention, 2016.

2) Kim KS, Bae CW. Trends in survival rate for very low birth weight infants and extremely low birth weight infants in Korea, 1967-2007. Korean J Pediatr 2008;51:237-42.

3) Matthews TJ, MacDorman MF. Infant mortality statistics from the 2010 period linked birth/infant death data set. Natl Vital Stat Rep 2013;62:1-26.

4) Kim MH. Changes in birth rates of low birth weight and premature infants in Korea over the past 7 years. Korean J Pediatr 2008; 51:233-6.

5) Goldenberg RL, Culhane JF, Iams JD, Romero R. Epidemiology and causes of preterm birth. Lancet 2008;371:75-84.

6) Horbar JD, Badger GJ, Carpenter JH, Fanaroff AA, Kilpatrick S, LaCorte M, et al. Trends in mortality and morbidity for very low birth weight infants, 1991-1999. Pediatrics 2002;110:143-51.

7) Lemons JA, Bauer CR, Oh W, Korones SB, Papile LA, Stoll BJ, et al; NICHD Neonatal Research Network. Very low birth weight outcomes of the National Institute of Child Health and Human Development Neonatal Research Network, January 1995 through December 1996. NICHD Neonatal Research Network. Pediatrics 2001;107:e1.

8) Fanaroff AA, Stoll BJ, Wright LL, Carlo WA, Ehrenkranz RA, Stark AR, et al; NICHD Neonatal Research Network. Trends in neonatal morbidity and mortality for very low birth weight infants. Am J Obstet Gynecol 2007;196:147.e1-8.

9) Kusuda S, Fujimura M, Sakuma I, Aotani H, Kabe K, Itani Y, et al; Neonatal Research Network, Japan. Morbidity and mortality of infants with very low birth weight in Japan: a center variation. Pediatrics 2006;118:e1130-8.

10) Shim JW, Kim MJ, Kim EK, Park HK, Song ES, Lee SM, et al; Committee on Data Collection and Statistical Analysis, The Korean Society of Neonatology. The impact of neonatal care resources on regional variation in neonatal mortality among very low birth weight infants in Korea. Pediatr Perinat Epidemiol 2013;27:216-25.

11) Lee HH, Kim TY, Shin SH, Sung TJ. Changes in the outcomes of neonatal intensive care unit at a single center over 12 years. Korean J Pediatr 2009;52:881-7.

12) Chang YS, Park WS. Strategies to overcome the limit of viability of microprimie. Neonatal Med 2013;20:258-67.

13) Chang YS, Ahn SY, Park WS. The establishment of the Korean Neonatal Network(KNN). Neonatal Med 2013;20:169-78.

14) Zonnenberg I, de Waal $K$. The definition of a haemodynamic significant duct in randomized controlled trials: a systematic literature review. Acta Paediatr 2012;101:247-51.

15) Dempsey EM, Al Hazzani F, Barrington KJ. Permissive hypotension in the extremely low birthweight infant with signs of good perfusion. Arch Dis Child Fetal Neonatal Ed 2009;94:F2414

16) Lee J, Kim HS, Jung YH, Choi KY, Shin SH, Kim EK, et al. Oropharyngeal colostrum administration in extremely premature infants: an RCT. Pediatrics 2015; 135:e357-66.

17) Jobe AH, Bancalari E. Bronchopulmonary dysplasia. Am J Respir Crit Care Med 2001;163:1723-9.

18) Pi SY. Manual of neonatal care. 2nd ed. Seoul: The Korean Society of Neonatology, 2008:184-9, 247-8, 235-40, 452-5, 350-4.

19) Papile LA, Burstein J, Burstein R, Koffler H. Incidence and evolution of subependymal and intraventricular hemorrhage: a study of infants with birth weights less 1,500 gm. J Pediatr 1978; 92:529-34.

20) Bell MJ, Ternberg JL, Feigin RD, Keating JP, Marshall R, Barton L, et al. Neonatal necrotizing enterocolitis. Therapeutics decisions based upon clinical staging. Ann Surg 1978;187:1-7.

21) Smith PB, Ambalavanan N, Li L, Cotten CM, Laughon M, Walsh MC, et al. Approach to infants born at 22 to 24 weeks' gestation: relationship to outcomes of more-mature infants. Pediatrics 2012;129:e1508-16.

22) Kattwinkel J, Perlman JM, Aziz K, Colby C, Fairchild K, Gallagher J, et al. Neonatal resuscitation: 2010 American Heart Association Guidelines for Cardiopulmonary Resuscitation and Emergency Cardiovascular Care. Pediatrics 2010;126:e1400-13.

23) Hellström A, Smith LE, Dammann O. Retinopathy of prematurity. Lancet 2013;382:1445-57. 
24) Bell EF, Acarregui MJ. Restricted versus liberal water intake for preventing morbidity and mortality in preterm infants. Cochrane Database Syst Rev 2014:CD000503. doi: 10.1002/ 14651858.CD000503.pub3.

25) Barton L, Hodgman JE, Pavlova Z. Causes of death in the extremely low birth weight infant. Pediatrics 1999;103:446-51.

26) StranákZ, Velebil P, Stembera Z. Changes in causes of mortality in very low birth weight neonates. Ceska Gynekol 2002;67 Suppl 1:46-9.
27) Lapillonne A, Griffin IJ. Feeding preterm infants today for later metabolic and cardiovascular outcomes. J Pediatr 2013;162:S716.

28) Jeon GW, Park SE, Choi CW, Hwang JH, Chang YS, Park WS. The effects of early enteral feeding in extremely low birthweight infants. Korean J Pediatr 2005;48:711-5.

29) Beardsall K, Vanhaesebrouck S, Ogilvy-Stuart AL, Vanhole C, Palmer CR, van Weissenbruch, et al. Early insulin therapy in very-low-birth-weight infants. N Engl J Med 2008;359:1873-84. 